\title{
安全・安心な生活とICT研究会 (ICTSSL)
}

「安全·安心な生活とICT研究会 (ICTSSL)」では, 平成2 1 年5月に第三種研究会「安全·安心な生活のための情報通信ネット ワーク」を立ち上げ，「安全·安心な生活のための情報通信システム」時限研究專門委員会を経て，平成28年6月から第一種研究 会として新たな活動を開始しています。これらの活動期間の中で，情報通信を基盤としながらも，人の活動や運用マネジメントの 重要性を認識し，研究会領域をICTに拡大しました。

現在，我が国では，首都直下地震や南海トラフ巨大地震の発生が危惧されており，広域にわたって甚大な被害が発生するととも に,大規模な社会混乱の発生が想定されています，この国難と言うべき状況を乗り越えるべく,近年では「レジリエントな社会形成」 をキーワードとして, 八ード対策からの発生被害量を極小化する被害抑止と, ソフト対策からの被害拡大を極小化する被害軽減を 効果的に連携させる必要性が求められています。

このような状況を鑑み，本研究会は，災害や危機管理をフィールドとして，工学・理学・社会科学の学際的な研究並びに実務経 験に基づく現場の課題解決に関する実証等についての成果共有の場として活動しています，そのため，専門分野で御活躍されてい る研究者のみならず, 新たな研究領域に挑戦する研究者, これから研究領域を確立する若手研究者や学生, 実務として社会還元を 推進する企業の方々など，分野・業種の垣根を越えて，本研究会に集結し，それぞれの立場・経験から活発な議論が繰り広げられ ています

平成28年から「優秀研究賞」「研究奨励賞」「安全·安心ベストプラクティス 賞」の3種類の表彰制度を制定しました。施行開始となった日作年は，2件の研 究が優秀研究賞, 3件の研究が研究奨励賞, 2件の研究が安全・安心ベストプ ラクティス賞を受賞しました，特に，「研究将励賞」は，学生と若手発表者を対 象に研究成果を表彰するものであり, 研究会参加への意欲向上と研究の発展的 推進につながっています，また，「安全·安心ベストプラクティス賞」では，社 会実装を中心とした研究成果を表彰し，積極的な社会発信・社会貢献に拍車を かけています，平成29年においても，興味深く，高い社会貢献を期待できる 研究が多く発表されており, どの研究が受賞するか, 期待に胸を膨らませるば かりです

本年度は，5月にはNEXCO 東日本東北支社・仙台東管理事務所，7月には

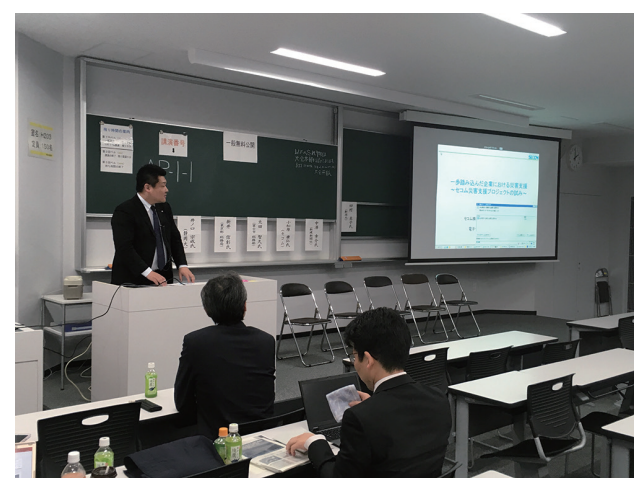

写真 1 研究会での発表の様子 (2017年 総合大会) 香川大学において研究会を開催しました。10月には静岡県地震防災センター，1月には機械振興会館において研究会を開催する 予定です，防災対策を推進している地域での開催 (本年度は仙台・静岡)では, 現場の実態を学ぶべく, 現地視察も企画しています

理論的な研究のみならず, 実験的研究, 実証研究等, 幅広く皆様からの参加をお待ちしております。「安全・安心な社会」につ ながる研究を, 奮って御発表下さい.

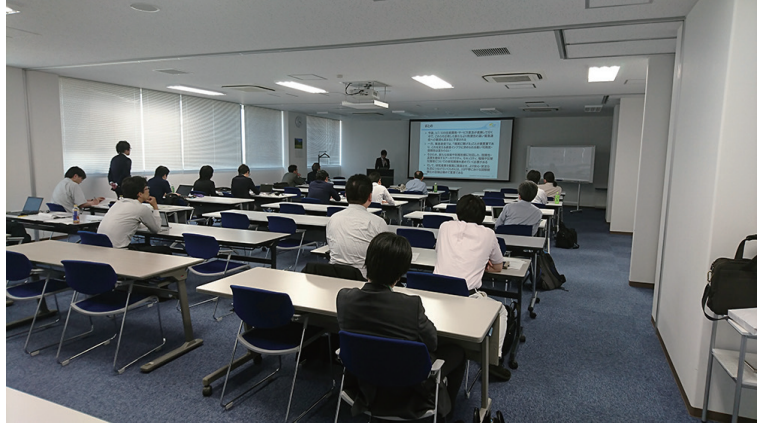

写真 2 研究会での発表の様子 (NEXCO仙台東管理事務所)

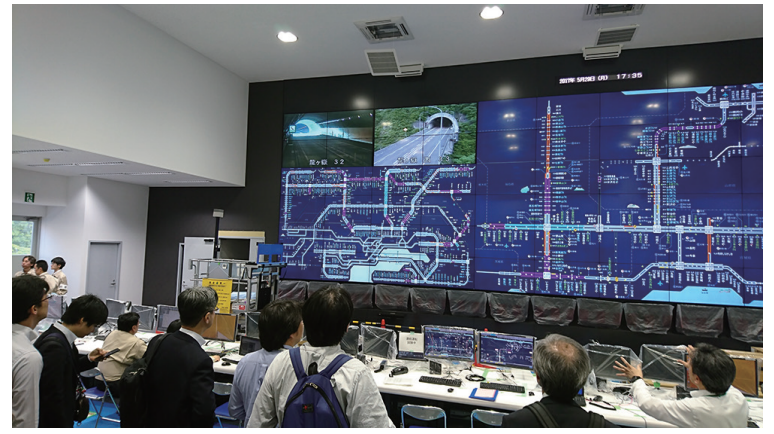

写真3 現地視察の様子 (NEXCO仙台東管理事務所)

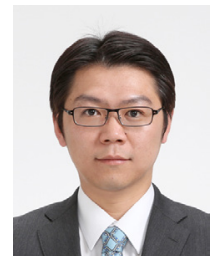

井ノ口宗成 (正員)

2003 京大·工卒, 2008京大大学院情報学研 究科博士号取得。同年新潟大·災害研・助教を経 て、2015から静岡大・情報・講師。災害復興過 程における効果的な情報システムのデザインから開 発，災害対応現場における実装までを一貫して研究 2009 地域安全学会論文奨励賞，2014グッドデザ イン賞，2017ICTSSLベストプラクティス賞を各 受賞. 2013 から国際危機管理学会日本支部·理事, 2016 からICTSSL 幹事。 